\title{
THE DUTCH APPROACH TO INFORMAL LIFESTYLES: FAMILY FUNCTION OVER FAMILY FORM?
}

\author{
W. M. SCHRAMA*
}

\section{ABSTRACT}

In this article, the Dutch approach to informal lifestyles will be analysed on the basis of legal developments during the period 1970-2006 in a number of legal areas, such as landlord and tenant law, inheritance tax law, and social security law. The debate between family function and family form is the point of departure. This is highly relevant, since the number of couples living together unmarried is steadily increasing in the Netherlands. Non-marital cohabitation actually consists of a number of different types, including pre-marital, postmarital, and long-term cohabitation. However, surprisingly little sociological data on informal lifestyles are available, so it is difficult to combine sociological research with legal data. The results of the legal analyses demonstrate that the Dutch legal system has generally accepted non-marital cohabitation in most areas by recognizing both the emotional and economic ties between cohabiting partners. However, in the fields of family law, inheritance law, and criminal and criminal procedural law, informal lifestyles are mostly ignored. This is hardly acceptable, taking into account the aim of most of the provisions, which is generally not so much the recognition of the family form as such, but the recognition of the underlying family functions. In this respect, the form over function fields should be fundamentally reconsidered in order to do justice to the changed social reality.

\section{N T R O D U C T I O N}

Non-marital cohabitation is a fascinating subject. Not only does it raise questions from a sociological and demographical perspective but also it gives rise to complex legal issues. The number of partners living together outside an informal relationship in The Netherlands is, as in many European countries, ${ }^{1}$ increasing, as is the number of children born and raised in this type of relationship. The aim of this article is to

\footnotetext{
* Senior lecturer and researcher in family law at the Utrecht Centre for European Research into Family Law (UCERF) of the Molengraaff Institute for Private Law, Utrecht University, The Netherlands. This article has been partially supported by an Innovative Research Grant from the Dutch Scientific Organization.

International Journal of Law, Policy and the Family, Vol. 22, No. 3,

(C) The Author [2008]. Published by Oxford University Press. All rights reserved. For permissions, please e-mail: journals.permissions@oxfordjournals.org.oxfordjournals.org.
} 
give an insight into the Dutch social and legal developments concerning non-marital cohabitation and to explain these developments in terms of the dichotomy between family function and family form. ${ }^{2}$ It will be argued that the Dutch approach to informal lifestyles may generally be a model for other legal systems, which are also struggling with the question of how to respond to these social developments. ${ }^{3}$ However, in a limited number of legal areas some serious problems still exist, so the Dutch model is still far from perfect. In dealing with these issues, this article also discusses a number of questions raised in the debate over the relationship between family form and family function.

Before presenting an overview of the Dutch law on non-marital cohabitation, a number of social developments regarding lifestyles will be discussed in order to give an insight into the meaning of non-marital cohabitation in Dutch society. As lifestyles are potentially relevant to a great deal of legal areas, only the most important legal areas will be considered. The focus is on the way non-marital cohabitation has 'conquered' the different fields of law. Less attention will be paid to the specific terms used in the legislation to define informal lifestyles. I will then take a closer look at the legal areas that so far seem to be almost immune to reform, first family law, then inheritance law and, finally, criminal and criminal procedural law. The article will end with some general remarks regarding the Dutch approach as a possible model for other legal systems.

\section{DEMOGRAPHIC DEVELOPMENTS}

In order to put non-marital cohabitation in a proper legal perspective, it is necessary to deal briefly with a number of social developments. ${ }^{4}$ However, it is difficult to find reliable data on non-marital cohabitation. Surprisingly, little demographic and sociological research has been carried out in the Netherlands that explores informal lifestyles. Nonmarital cohabitation is a relatively new phenomenon in the Netherlands, at least over the last 100 years. ${ }^{5}$ It is only since the end of the 1960 s that a growing number of couples have cohabited without being married. The status of non-marital cohabitation is rather different from the position of concubinage during earlier historical periods; it is no longer restricted to specific social groups, and the number of persons involved is large and not limited to a specific stage in life ${ }^{6}$ At the beginning of the 1980s, some 200,000-250,000 couples were estimated to be living together unmarried, whereas in 2006 this had increased to 747,000 couples. Figure 1 illustrates the trend over the last decade.

Not only has the absolute number of cohabiting couples increased but also the position relative to other household types has changed. Figure 2 shows the relative positions of different types of households. 


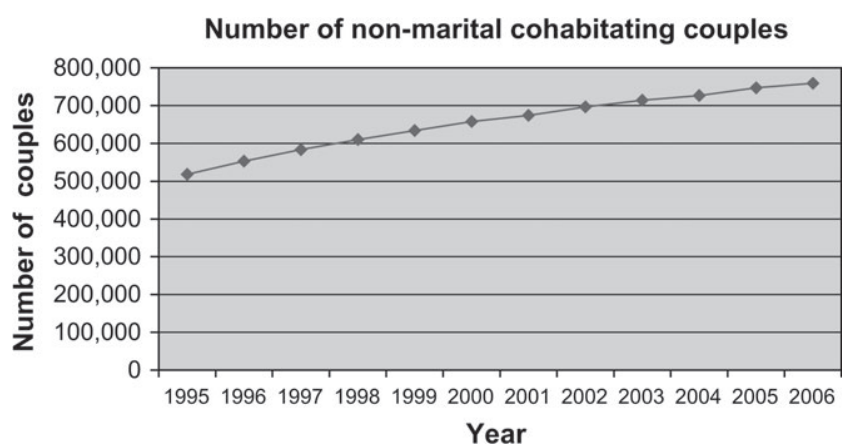

Figure 1. Non-marital cohabitation relationships in absolute numbers per year (Statistics Netherlands).

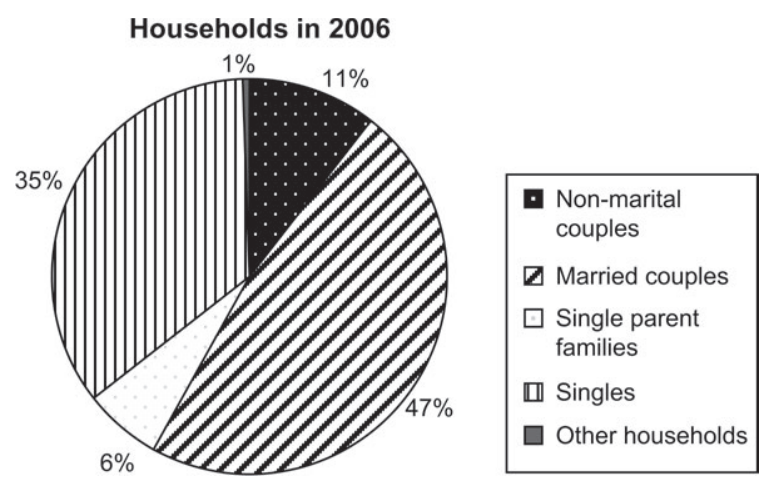

Figure 2. Relative division of households in 2006 (Statistics Netherlands).

As can be seen from this figure, non-marital cohabitation represents 11 per cent of all households. Two in 11 cohabiting couples are nonmarital. Three decades ago, such figures were inconceivable. ${ }^{7}$

The number of children born outside marriage has increased rapidly over the past few decades and is currently 35 per cent of all children. ${ }^{8}$ In 2006, 300,000 of 760,000 unmarried couples had at least one child (cumulatively 420,000 children). These children are mostly children of both partners together, although there is also a smaller number of children who are part of a post-marital unmarried cohabitation with a new partner. ${ }^{9}$ Figure 3 shows the steady increase in the number of nonmarital couples with children.

Statistics Netherlands has collected data for a distinct number of birth cohorts regarding the number of non-marital couples who marry, split up, or continue to live together unmarried. One of the findings is that long-term cohabitation only accounts for a relatively small proportion, as can be derived from Figure 4, which gives the percentage 


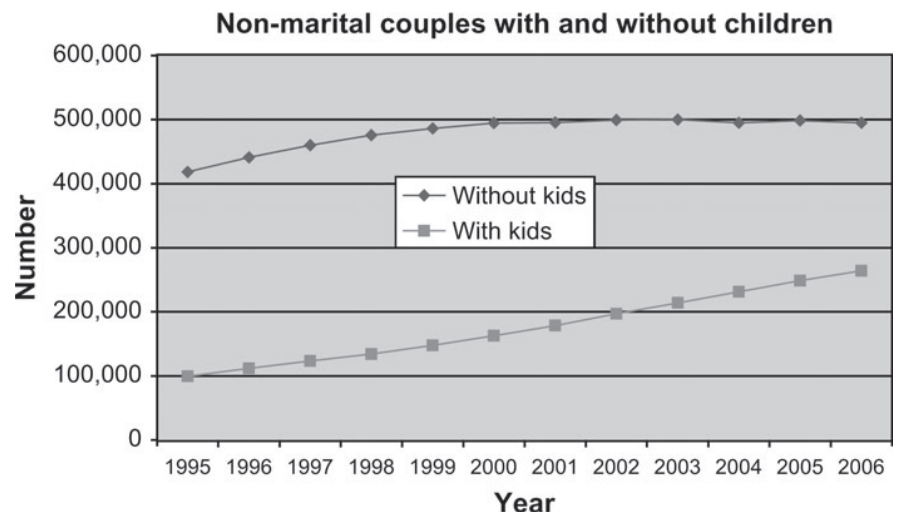

Figure 3. Non-marital couples with and without children in absolute numbers (Statistics Netherlands).

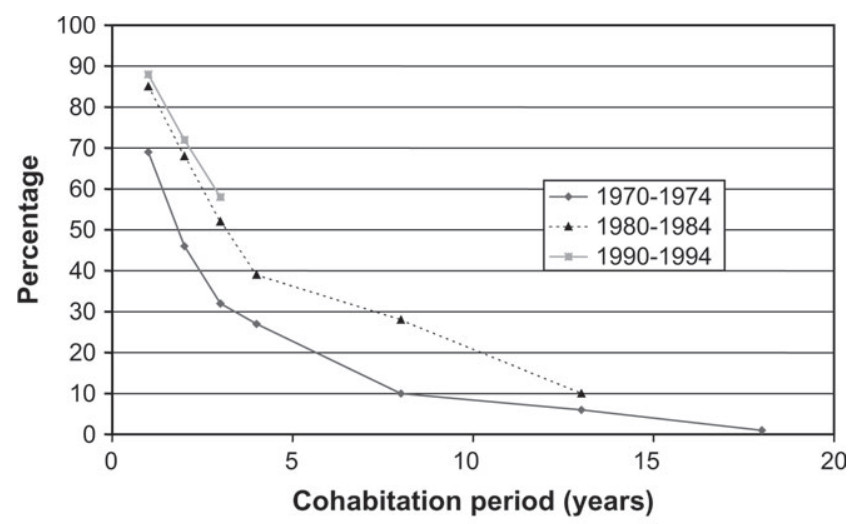

Statistics Netherlands, Onderzoek Gezinsvorming 1998

Figure 4. Percentage of women aged 20-24 years at the start of the cohabitation, who are still living together after a variable period of time, presented for three different cohabitation cohorts.

of women who are still in a cohabitation after a various time periods. It is clear that a considerable proportion of non-marital relations last for at least 5 years.

Perhaps the most important lesson to be learned from a sociological perspective is that it is misleadingly simple to perceive non-marital cohabitation as one single lifestyle. A distinction has to be made between at least three types of cohabitation relationships: ${ }^{10}$

1. Pre-marital cohabitation: This is where young people who live together for only a limited period of time (mostly between 0 and 5 years). A large minority of these cohabitants eventually separate. The remainder eventually marry. This is the largest group of cohabitants. 
2. Post-marital cohabitation: This is where one or both partners were previously married or lived in a long-term non-marital relationship. There are no specific data on the proportion of post-marital cohabitants who convert their relationship into marriage. Of the unmarried couples with children, 28 per cent are in post-marital relationships.

3. Long-term non-marital cohabitation, which the partners consider to be an enduring alternative to marriage or a registered partnership. Only a relatively few cohabitants live together for a long period.

Each category has its own characteristics, but the existing sociological research does not yet provide a sufficient insight into the exact differences between the groups. It is not possible to make general observations about marital and non-marital cohabitation in terms of the function and form debate, since it is first necessary to investigate why the legislature only legislates about marriage. Lawyers and the legislature should, however, be well aware of the diversity of non-marital cohabitation, since each of the categories has its own legal problems.

\section{FAMILY FUNCTION AND FAMILY FORM}

\section{INTRODUCTION}

How has the legal system reacted to this increase in informal lifestyles? Non-marital cohabitation has gradually been identified by the legislature as a lifestyle with important economic and emotional functions and therefore as legally relevant. This section will describe the legal developments relating to informal lifestyles. This brief and recent legal history will demonstrate that legal policy makers in The Netherlands chose family function rather than family form, albeit not in every area of the law. The exceptions where family form prevails over family function are family law, inheritance law, and criminal and criminal procedural law, which will be discussed in section 4 . Before dealing with these developments, it is important to note that the Dutch Constitution does not have a provision that constitutionally protects marriage or married families. This facilitates the legal recognition of non-marital lifestyles. ${ }^{11}$

\section{MAINTENANCE BETWEEN FORMER SPOUSES}

The gradual legal recognition of non-marital cohabitation started back in the 1970s in the field of maintenance law. A proposal was discussed in Parliament to end the right of a former spouse to maintenance from his/ her ex-spouse by operation of law upon the remarriage of the ex-spouse. It was argued that the new spouse would be under a legal duty to maintain that former spouse. However, a Member of Parliament proposed to 
amend the proposal by extending this provision to the situation in which the former spouse was living together with a new partner without being married. The underlying rationale was to prevent ex-spouses preferring 'concubinage' to marriage for this reason. ${ }^{12}$ Although the government attempted to argue that there was no difference between marriage and non-marital cohabitation in this respect, actually there was, since the former spouse would only be entitled to maintenance from a new partner if they were married. This argument was not the sole reason for the critical reception of the MP's amendment, since the wording ${ }^{13}$ was not welcomed either. ${ }^{14}$ Furthermore, it was correctly argued that the provision was superfluous, since the courts could always take into account all the relevant factors, including cohabitation as a factor reducing the needs of the former spouse. Despite this criticism, the amended provision came into force in 1971, which clearly signalled the awareness of the legislature of changing social conditions. Interestingly, in 2005 the debate was reopened with the Minister of Justice consulting a number of Dutch organizations on whether the provision should be reconsidered for the sake of legal certainty. The outcome was unanimous that a change in the legal provision was not necessary. ${ }^{15}$

\section{LANDLORD AND TENANT LAW}

It did not take long before the next step was taken on the road towards the recognition of informal lifestyles in the field of private law. In 1979, the legal position of a partner living together with a tenant was considerably improved. A person living in a stable household with a tenant for a minimum period of 2 years is entitled to certain rights in relation to the tenant and, more importantly, to the landlord. The tenant and his/her co-resident are enabled to request the landlord to treat him or her as a co-tenant. If the landlord refuses, the tenant and co-resident can apply at the court. ${ }^{16}$ The status of co-tenant is important, since the co-tenant may take over the rental contract if the tenant wants to terminate his/her contract. Even more important is that in the case of separation, the co-tenant may request the court to determine which partner is entitled to occupy the house.

Again the proposal was an extension made by Parliament to a narrower proposal made by a Minister. The Minister had intended only to create a right to take over the lease when the tenant died and was reluctant to accept the extension. The left-wing parties insisted on it however, and in this way the co-tenant's rights were substantially improved when a non-marital relationship breaks down.

\section{INHERITANCE TAX LAW}

Only 2 years later, in 1981, non-marital cohabitation entered the area of inheritance tax law (Successiewet 1956). ${ }^{17}$ This is the first field of law 
in which the relationship between an unmarried couple became directly relevant in relation to the State. The legislature decided that it was no longer acceptable to ignore non-marital cohabitants. This group experienced a number of tax problems, notably that there was no exemption from inheritance tax for a surviving non-marital partner. Furthermore, the tax rate was relatively high. ${ }^{18}$ This meant that a considerable amount of the estate had to be paid in tax. But the government believed that the death of one of the partners should not result in a considerable deterioration of the financial circumstances of the survivor partner solely because of this taxation. It did not, however, propose that they should be treated totally in the same way as married couples. ${ }^{19}$ Thus, since 1981 a taxation system has been applied that takes into account non-marital cohabitation.

In 2002, the inheritance tax law (Successiewet 1956) was again amended with respect to non-marital cohabitation. A new definition of a partner was added to the already existing categories. ${ }^{20}$ The incentive for the government was to erase, as far as possible, the differences between married and unmarried couples. ${ }^{21}$ When a surviving partner qualifies under the Act, the same exemption and tax rate will apply as to married and registered couples. ${ }^{22}$ In conclusion, inheritance tax law currently consists of a rather complex system with a number of different categories in which non-marital couples may qualify. If they do, their legal position is similar to the position of spouses.

\section{PROTECTION OF VULNERABLE ADULTS}

The protection of vulnerable adults is the next field of law in which non-marital cohabitation was recognized in 1982. Yet another definition was introduced, namely, the 'other life partner' (andere levensgezel). ${ }^{23}$ Once more, the Second Chamber of Parliament requested the Minister to adjust the original bill in order to give a life partner equal rights to a spouse. These rights are twofold: on the one hand, a life partner may apply to the court for an order to place the property of the partner under administration and, on the other, the life companion is one of the persons who has preference in the appointment as the administrator of the property by the court. The Minister was initially reluctant to broaden the scope of the provision, since it would cause difficulties in determining who would qualify as a life companion. Despite these misgivings, the Minister finally accepted the argument that social reality demanded an extended scope of application. ${ }^{24}$ The term 'life partner' refers to relationships that are similar to those of married couples. ${ }^{25} \mathrm{~A}$ joint household is not a prerequisite for the application of the provision and the sex of the partner is irrelevant. The same provisions are currently applicable regarding the appointment of a curator and the judicial protection of vulnerable adults. ${ }^{26}$ 
6. SOCIAL SECURITY LAW AND OTHER FIELDS OF LAW

In 1987, social security law was reformed. In 1965, when the Social Assistance Act was introduced, the time had not yet come to include non-marital partners. ${ }^{27}$ However, the courts soon interpreted the 1965 Act so as to include non-marital partners, giving them an equal position. ${ }^{28}$ In 1987, this case law was laid down in statutory form. ${ }^{29}$ The decisive criterion turns on the actual needs and means of the applicant, so that marriage is no longer perceived as a prerequisite. Non-marital partners with a joint household are legally presumed to share financial and non-financial responsibilities and therefore it appears only logical to take the financial means of the partner of the person applying into account. ${ }^{30}$ The sex of the partners is not relevant. ${ }^{31}$ The subsequent reform in 2004 did not affect the position of non-marital cohabitants.

Further developments in other areas of law include the incorporation of non-marital cohabiting partners in the field of liability for the death of a person who maintained his or her partner (1992). ${ }^{32}$ Since 1984, a number of legal provisions from income tax legislation have been extended to non-marital cohabitation, thereby placing it in these respects on an equal footing with marriage. In the Income Tax Act 2001, a new term for non-marital cohabitants (fiscal partnership) has been introduced in order to meet the requirements of the equality principle, which was aimed at a further recognition of the social trends concerning informal lifestyles. ${ }^{33}$

\section{SUMMARY}

These developments clearly reveal an approach by the legislature that takes into account social developments in almost all areas in which nonmarital cohabitation might be of interest. Moreover, they demonstrate that it is possible to define the group of non-marital cohabitants, even in fields of law in which many individual cases have to be decided and where fraud might be a realistic risk, such as social security law and tax law. ${ }^{34}$ The most important aspect of this legal trend is that the law perceives both the emotional and economic ties between partners as legally relevant. Such an approach enables the legislature to dispense with the link between family form and family function. Marriage is no longer a prerequisite in order to qualify as a family. Almost all areas of law have been reformed so that non-marital cohabitation now has its own status. There appear to be no major differences in trends in private law and public law and there is definitely no sign of favouring one status over the other. The effects of these legal developments for non-marital couples themselves are both positive and negative. It is surprising to note that Parliament has been an important and often even a decisive factor in amending the law. If it were not for the Second Chamber of Parliament, many changes would not have been introduced at such an early stage. 
FAMILY FORM OVER FAMILY FUNCTION

It is striking to note that there are three important legal areas in which the social developments relating to non-marital cohabitation have not been translated into legal recognition: family law, inheritance law, and criminal and criminal procedural law. In this part these topics will be described (sections 1-3) and discussed (section 4).

\section{FORM OVER FUNCTION IN FAMILY LAW}

A vital exception to the general approach of translating social reality into legislation is the field of family law. This is particularly relevant, since family law has consequences beyond the family itself. Legal concepts of marriage and the family are defined in family law, but play an important role outside family law, eg, in tax law and criminal law, where marital status has far-reaching legal effects. Within family law, two aspects have to be discerned: first, the legal relationship between partners and their children and, second, the legal relationship between the partners themselves.

\section{A. Parents and Children}

There is a substantial difference between the position of children born within and outside wedlock, not only relating to parentage law but also with respect to parental authority. The unmarried father ${ }^{35}$ who is living together with the mother at the time of the child's birth, needs to formally recognize his child in order to become its legal parent. ${ }^{36}$ The husband, on the contrary, who is married to the mother when the child is born, is the legal father by operation of law. ${ }^{37}$ Unfortunately, there are almost no empirical data available on the number of fathers who for one reason or another do not recognize their child. Sociological research on registered partners, however, demonstrates that a proportion of male registered partners do not recognize their children. ${ }^{38}$

Even if an unmarried father recognizes his child with the consent of the mother, ${ }^{39}$ he does not automatically share parental authority with the mother. Only the mother exercises parental authority by operation of law. ${ }^{40}$ In order to exercise joint parental authority, the father and the mother have to be recorded in the register as exercising joint parental authority. ${ }^{41}$ Although this request will generally be granted, the parents have to take certain steps. ${ }^{42}$ If a father has not recognized his child, he cannot exercise parental authority over the child jointly with the mother. ${ }^{43}$ Again, there are no empirical data on the number of legal fathers who do not exercise joint parental authority with the mother. In contrast, married men have joint parental authority by operation of law. Therefore, almost all married men exercise joint parental authority, 
in principle also after divorce. ${ }^{44}$ In short, the differences between the two groups of children (and fathers) are substantial, since legal parenthood has far-reaching implications in the field of nationality law, the law of names, parental authority, inheritance law, social security law, income tax law, inheritance tax law, and issues concerning contact and information.

If a biological father wishes to recognize his child after a relationship has broken down, which is usually the period in which conflicts between the partners arise, it might not be easy to obtain the cooperation of the mother that is necessary for the recognition of children under the age of $16 .{ }^{45}$ There is a whole body of case law in which fathers apply for permission from the court to recognize their children. These cases are difficult to settle, in particular if the mother has already consented to the recognition of the child by another man with whom she constitutes a new family. In most cases, permission is granted, even when the child has already been recognized by another man after the biological father applied for permission from the court. ${ }^{46}$ Even if the father does succeed in establishing family ties with his child by recognition, it is still not easy to obtain parental authority after a relationship has broken down. The mother will generally not be inclined to be recorded in the register as exercising joint parental responsibility with the father. The Civil Code allows a legal father only to apply for sole parental responsibility, which is difficult to obtain if the mother is exercising sole parental responsibility. ${ }^{47}$ However, the Dutch Supreme Court has accepted that, contrary to the legal provisions, a legal father may ask the court an order for joint parental authority with the mother. ${ }^{48}$ To withhold such a right would constitute an infringement of article 6 of the European Convention on Human Rights. The legal position and status of children are therefore to a large extent determined by the relationship status of their parents. However, it is difficult to determine the significance of these differences in practice, since hardly any empirical data are available.

\section{B. Partners}

The legal relationship between unmarried partners is complex. ${ }^{49}$ About 50 per cent of non-marital cohabiting couples have concluded a written cohabitation contract, drawn up by a notary. ${ }^{50}$ However, a cohabitation contract often does not resolve the problems experienced when a relationship breaks down. ${ }^{51}$ Various questions arise. Which property belongs to which partner? Is compensation due for money invested in the other partner's property or for non-financial investments? Who will continue to rent the dwelling? Who is liable for debts incurred during the relationship?

The general rules of contract law and property law are applicable to relations between the partners both during a relationship and after it 
has broken down. There is no specific legislation dealing with informal relationships and the law relating to marriage cannot be applied by analogy. The problem is that contract law and property law are primarily designed to regulate economically based relations and transactions where each party acts primarily in his or her own economic interest. Therefore, the love-based nature of the relationship between cohabitants, which dominates their financial behaviour, is not reflected in these areas of the law. As a result, the disentangling of the closely knit legal positions of both partners is dependent largely on chance, since during the relationship it is usually irrelevant who pays what, who owns what, and who contributes what to the other partner. The economic transactions between the parties are typically not determined by the risk of the relationship breaking down. This love-based nature of the relationship is not limited to non-marital cohabitation but also manifests itself in marriage and a registered partnership. In this sense, marriage, registered partnership, and non-marital cohabitation are all species of the genus love relationships. However, Book 1 of the Dutch Civil Code provides a clear system of coherent provisions regarding the financial and property consequences of marriage and registered partnership, in which the love-based nature of the relationship is taken into account. A number of these specific legal provisions have been designed to compensate (maintenance, property distribution) spouses for the negative effects of a traditional division of tasks. Such systems are completely absent in the case of non-marital relationships, but the effect of the relationship in terms of economic transactions might well be similar to that of a married family. ${ }^{52}$

This causes two major problems. One is legal uncertainty about the application and interpretation of contract law and property law in individual non-marital cohabitation disputes. The other is injustice towards partners who have substantially invested in the relationship by taking care of children or contributing to the other partner's assets. Both problems intensify each other. Courts have to deal mostly with property disputes, ${ }^{53}$ conflicts concerning the dwelling, ${ }^{54}$ and compensation claims for contributions by one partner to the other partner's assets. ${ }^{55}$ Legal certainty is at stake in these disputes, since hardly any clear pattern of interpretation can be discerned, despite a growing body of case law in this respect. Similar claims result in different outcomes, depending on the court and the lawyers involved and depending on the way in which claims are presented to the court. The differing outcomes might be due to the fact that contract law and property law can be interpreted in a way that allows the courts to take into account the facts of each individual case. Non-marital cohabitation with its different types of relationships is itself rather diverse, which implies that clear-cut rules are difficult to construct. However, the unpredictability is of a more fundamental nature. There is little 
consensus on the legal significance of love-based relationships, which is important since this relationship constitutes the framework for the financial behaviour of the partners. In some decisions, the court hardly regards the relationship as a relevant factor at all, while in other decisions the opposite is true. ${ }^{56}$

Apart from legal uncertainty, there is the injustice caused by the discrepancy between social reality and legal presumptions concerning the behaviour of partners in a love relationship. A partner who has invested substantially more in the relationship than the other may be left empty handed, in particular if this investment consists in taking care of the children. Although most women in the Netherlands substantially reduce or completely give up labour participation after childbirth, the question whether a partner whose earning capacity has been considerably diminished has a right to compensation when the relationship breaks down has never been raised in the courts. The courts find ways to do justice in cases concerning investments of a different nature, like financial investments in the other partner's property, but in a number of cases the actual meaning of non-marital cohabitation as an emotional and economic unit is simply not taken into account..$^{57}$

\section{FORM OVER FUNGTION IN INHERITANGE LAW}

Although Book 4 of the Civil Code on inheritance law was amended in 2003, after a debate in Parliament over 30 years, the position of a surviving non-marital cohabitant is still far from appealing. Even if some improvements have been made, the reforms have in some respects widened the gap with marriage. A surviving spouse acquires all the assets of the deceased's estate unless the deceased spouse's will provides that the entire section in the Civil Code on the intestate succession of a spouse should not apply. ${ }^{58}$ The children of the deceased spouse acquire a right to a pecuniary claim against the surviving spouse, which is only enforceable if the spouse is declared bankrupt or dies. This right has not been extended against a surviving non-marital cohabitant. The surviving partner is not an ab intestato heir either, whereas a spouse is. ${ }^{59}$ This implies that the children or other family members of the deceased cohabitant inherit the complete estate, if there is no will. The new inheritance legislation introduced a new instrument that purports to take care of the informal surviving partner after the death of his partner. ${ }^{60}$ Using this instrument, the surviving informal partner may be entitled to the estate. It should be stated in each partner's will that the surviving partner inherits the estate and a clause of non-enforceability should be included in the will. The children's pecuniary claim as forced heirs against the surviving partner can thus be made enforceable after the death of the surviving partner 
or after another condition is met, such as remarriage of the partner. ${ }^{61}$ In order to use this provision, the partners should have lived together in a 'joint stable household' on the basis of a cohabitation contract drawn up by a public notary.

The new inheritance legislation has also improved the position of a surviving spouse and a non-marital cohabiting partner with respect to the right to the dwelling and household effects for a limited period of 6 months after the death of the partner. ${ }^{62} \mathrm{~A}$ spouse has, however, more extensive statutory rights, which are of a mandatory nature. If necessary for the support of the surviving spouse, the heirs are required to cooperate in establishing a usufruct with respect to a number of goods, including the dwelling and household effects. These provisions are not extended to non-marital partners. ${ }^{63}$

In short, there are still considerable differences between the legal position of a formal and informal surviving partner with potentially farreaching financial implications. Reducing the gap between their legal position has not been considered or discussed in Parliament and the differences have not been challenged in the courts as a possible infringement of the principle of equality.

3. FORM OVER FUNCTION IN CRIMINAL LAW AND CRIMINAL PROCEDURAL LAW

In the field of criminal law and criminal procedural law, marriage and a registered partnership have important legal effects, which cannot all be enumerated here. Some criminal offences are not punishable when they are committed against a spouse, such as theft, fraud, and embezzlement. ${ }^{64}$ Concealment of a conspiracy to commit a number of offences is not punishable when this would result in the risk of the spouse of the accused being prosecuted. ${ }^{65}$ Providing assistance (so as to prevent arrest or prosecution) to a spouse who committed an offence is not punishable. ${ }^{66} \mathrm{~A}$ spouse will take over the right to file a complaint leading to the prosecution of an offence committed against his or her (deceased) spouse. ${ }^{67}$ Criminal procedural law gives a spouse a right to refuse to testify against his or her spouse, ${ }^{68}$ a right to refuse to cooperate with an inquiry against the spouse ${ }^{69}$ a right to select a lawyer for the accused spouse's defence, and a right to speak at the trial if the spouse has died as a result of the offence. ${ }^{70}$

In short, the status of a spouse brings about important legal effects in both criminal and criminal procedural law. Non-marital cohabitation does not play such a role. In general terms, the nature of criminal law (the principle of legality, the importance of legal certainty) is often invoked as an argument to draw a clear line between formal and informal lifestyles. This is demonstrated by a recent decision of the Supreme Court in which the principle of equality and the right to 
family life as contained in article 8 of the European Convention on Human Rights and Fundamental Freedoms were invoked by a partner who did not want to testify against her non-marital cohabiting partner. ${ }^{71}$ Dutch criminal procedural law provides spouses and registered partners with a right to refuse to testify against their spouse or registered partner. The Supreme Court refused to extend this provision to the unmarried cohabiting partner, who had lived with the accused man for over 15 years and with whom she had two children. The court invoked the principle of legal certainty and the nature of the provision as being an exception to the general principle of discovering the truth, which prevails over other interests. Family form is in this respect apparently more important than family function.

The principle of equality was also invoked in another case before the Supreme Court, ${ }^{72}$ concerning Article 316 s. 1 of the Criminal Code that prevents the prosecution of a spouse who steals from the other spouse. The defendant was in unmarried cohabitation and invoked the article. The Court rejected the equality principle on the ground that there was an objective and reasonable justification for the different treatment of spouses and non-marital cohabitants. It took into account that the prevention of prosecution contained in article $316 \mathrm{~s} .1$ is an exception to the general freedom of the Prosecutor to prosecute and that the exclusive applicability to spouses provides a clear and practicable limitation to this exception, which serves legal certainty.

Despite the fact that it seems rather difficult to qualify criminal and criminal procedural law by reference to the new lifestyles, legislation has recently made an important change. Article 304 of the Criminal Code increases the maximum penalty for the infliction of physical violence by a spouse on the other by one third. Since February 2006, this provision is equally applicable to a 'life companion'. ${ }^{73}$ This is a remarkable step, since it implies that the legislature has given more weight to the social function of non-marital cohabitation than to the legality principle ${ }^{74}$ which calls for legal certainty as to which acts are punishable. The significance of this legislative step is that it reveals a growing awareness of family function as an important aspect in the field of criminal law, which might even prevail over family form.

\section{WHY FAMILY FORM OVER FAMILY FUNCTION?}

\section{A. Family Law}

From an historical perspective, the distinction between married and unmarried families in family law is certainly explicable. But why did most other fields of law adjust to changed circumstances and why did family law not do so? Why does the law relating to children still make important distinctions between children born within and outside marriage? Should family form really prevail over family function? It is 
difficult to answer these complex questions and therefore the nature of this section is to a certain extent of a rather exploratory nature.

Parents and children. In 1998, the law on parentage was changed in order to abolish the distinction between children born within and outside wedlock, but did not contemplate extending the rights respecting children of married couples to children of unmarried couples. The law on parental responsibility has recently been amended on a number of occasions, but these changes focused on children born in relationships of same-sex couples and registered partnerships. ${ }^{75}$ Issues arising out of informal heterosexual parenthood have almost completely been ignored. ${ }^{76}$ In order to consider why this is so, it is necessary to identify the rationale for linking the law of parentage and parental authority with marriage. From an historical point of view, this question is easy to answer, but as society and social attitudes to parenthood and marriage itself have changed, the answer becomes more difficult. It is, even now, comprehensible to take marriage as a starting point for parentage and parental authority, as being a family form in which spouses are usually the biological, intentional, and social parents of the children born during the marriage. ${ }^{77}$ However, it is less obvious why the protection that is provided for children of married couples has not been extended to children of unmarried cohabitants, at least for different-sex couples. When a child is born during this type of relationship, is it less justified to presume that the partners are the child's biological, intentional, and social parents? $?^{78}$ With respect to parental authority, it is difficult to identify a valid reason not to attribute joint parental authority by operation of law to cohabiting parents from the moment of the recognition of the child by the father. ${ }^{79}$ The legislature needs to address these issues, since it is not family form that should be exclusively decisive. Legal certainty does not have to bar this step, since experiences in many fields of law demonstrate that it is possible to find practicable legal concepts and definitions for informal lifestyles.

Partners. With respect to the reforms of the law on the property and financial relations between cohabiting partners, one should realize that the focus in marriage law has recently been, on the one hand, on creating equality for same-sex couples and, on the other, on revising the matrimonial property regime. Furthermore, the introduction of registered partnership legislation in 1998 provided an alternative to couples who did not desire to marry. The underlying reason for attaching many legal effects in relations between spouses exclusively to marriage is historically logical. But here again social changes have created a situation in which family form and family function increasingly do not coexist. Whether a new direction in family law legislation is indicated depends on the 
nature of the provisions and the underlying rationale for linking the specific legal effect to marriage. Some provisions relate to the practical arrangements between partners living together on the basis of a lovebased relationship, such as those concerning evidence of property rights. These rules should not be exclusively based on family form. Whether the typical effects of marriage, such as the matrimonial property regime and maintenance, which are based on strong legal and social ties between the spouses of an economic and emotional nature, should be extended to all or a specific group of non-marital couples is a difficult question. In the Dutch legal literature, it has been argued that at least some legal provisions should be made for non-marital cohabitation. ${ }^{80}$ Although it is certainly true that not all types of non-marital cohabitation are functional equivalents of marriage, it is equally true that at least non-marital families with children are. In this respect, family form is in fact not decisive. The legislature should take these issues into consideration.

\section{B. Inheritance Law}

The main issue of the new inheritance law of 2003 was how to balance the rights of the surviving spouse with the rights of the family and in particular the children of the deceased spouse. Traditionally, family ties outweighed relationships based on marriage in inheritance law. ${ }^{81}$ Extending the hard-won position of the surviving spouse to non-married partners was just one bridge too far. Inheritance law also attaches a great deal of weight to formal relationships, whether partner or family relationships. Even though legal certainty is important in this field of law, due to the nature of inheritance law, there seems to be no real justification to prefer family form exclusively over family function. What is the underlying rationale for marking marriage as a relevant legal fact? Both emotional and economic relations between the spouses are relevant for the position of the surviving spouse. These ties between the spouses assume a joint investment in assets and a duty to take care of each other. Taking into account the changed social reality and social attitudes, is it justifiable that marriage and registered partnership monopolize all love-based cohabitation relationships? Here again, a proportion of all non-marital cohabitants will qualify in terms of an emotional and economic unit as well, at least with respect to the rationale of inheritance law, namely, protecting the surviving partner with whom the deceased kept close personal emotional and economic ties. The problem of how to identify the correct category of cohabitants is another question that has not been addressed by the legislature at all.

\section{Criminal and Criminal Procedural Law}

Criminal and criminal procedural law date back to 1886 and the framework of both codes have been basically preserved in this respect. 
In these fields of law, the interest of legal certainty and the legality principle has had a profound influence. In criminal law, marriage is relevant for a number of distinct reasons. First, marriage is an indicator of the existence of a close personal relationship. An example is the criminal law provision on the right to file a complaint leading to the prosecution of a certain offence in cases where the other spouse is not able to file the complaint himself or herself. This relationship implicitly presumes that the spouse is a person who is capable of managing the interests of the family, which might be at stake in case of prosecution. ${ }^{82}$ With respect to offences like theft, which are not punishable when they are committed against a spouse, the parliamentary history reveals that it was thought to be morally inappropriate for the state to pit two persons, who are so closely connected, against each other. In addition, the specific nature of the love relationship and its effects on the financial and property relations between the spouses was a distinct feature, which distinguishes these crimes between spouses and between other persons, where the property relations are clearly separated and not intertwined.$^{83}$ Concealment of a conspiracy to commit a limited number of offences is not punishable when this would result in the risk of the spouse of the accused being prosecuted. ${ }^{84}$ Those persons who, according to criminal procedural law, are not under a duty to testify, may not be forced to inform the authorities of these acts. ${ }^{85}$ Providing assistance (so as to prevent arrest or prosecution) to a spouse who committed an offence is not punishable ${ }^{86}$ Moreover, the spouse takes over the right to file a complaint leading to the prosecution of an offence committed against his or her (deceased) spouse. ${ }^{87}$ In these provisions, marriage is merely a species of the genus love-based relationship, which leads to the conclusion that there is no reason why family form should prevail over function.

The provisions in which marriage is legally relevant for its emotional significance aim to take into account the special relationship that does not exist for those not in a love-based relationship. ${ }^{88}$ This is not only in the interest of the spouses in an individual marriage but also relevant at state level, since it is in the public interest to protect relationships that are perceived as valuable. In these cases, one may wonder why the legislature still prefers a formal approach over a functional one.

\section{CONCLUDING REMARKS}

Since the early 1970s, important social developments have changed Dutch society, in particular with respect to lifestyles. This created a challenge for the legal system. Dutch law may be characterized in many respects by its open approach to this challenge. It is rather family function over family form that prevails in law-making policy. ${ }^{89}$ The 
debate on family forms is not polarized. Policy making has not been influenced at all by the fear that the status of marriage would be negatively affected by recognizing non-marital cohabitation. The fact that there is no constitutional provision conferring a special status to marriage facilitates such an open approach. The legislature has been trying to solve practical problems in a pragmatic way, albeit rather haphazardly. The legal position of non-marital couples is generally well balanced, since legal recognition brings about both advantages and disadvantages for unmarried couples. Both the emotional and financial significance of non-marital cohabitation have been recognized. An important incentive for the process of reform has been the desire of the legislature to meet the demands of the principle of equality. Therefore, in dealing with reforms in specific fields of law, the legislature has stressed the similarities between non-marital cohabitation and marriage rather than looking at the differences, resulting in a gradual assimilation of both statuses. In addition, unmarried couples themselves have invoked the principle of equality in the courts in order to obtain rights that are equal to those of married couples in a number of areas of the law. As a result of the case law, the legal position of unmarried couples has been improved considerably. ${ }^{90}$

In 2004, R. A. Macdonald of the Canadian Law Commission stated that in Canada, the law has invested so much policy significance in the concept of marriage that it has made the definition of marriage and not the policy goals themselves the focus of the political debate. This is not applicable to the Dutch situation. However, he continues: 'Yet, because previous extensions of benefits beyond married couples have always been an ad hoc response to particular situations, governments have never had to rethink the policy bases in question'.$^{91}$ This is certainly true in the case of the Netherlands. The legislature not only have to pay attention to the question of how non-marital cohabitants are to be defined but also, more importantly, should fundamentally reconsider the relationship between form and function in order to do justice in the new social conditions.

\section{NOTES}

${ }^{1}$ Kiernan, (2001), 1-21; Kiernan (2002), 57-76.

${ }^{2}$ Barlow (2005).

${ }^{3}$ Atkin, (2003-2004), 303-25; Barlow and James (2004); Barlow et al (2005); FreiburghausArquint (2000); Hausmann and Hohloch (2004); Hertz (2004); Holland (2008); Michel (2000); Noack (2001).

${ }^{4}$ See also Barlow (2005).

${ }^{5}$ Antokolskaia (2006).

${ }^{6}$ Liefbroer and Dykstra (2000).

${ }^{7}$ These changes cannot be attributed to changes in the population pyramid.

${ }^{8}$ Statistics Netherlands, Statline, http://www.cbs.nl.

${ }^{9}$ Schrama (2004), 26. 
${ }^{10}$ Schrama (2005), 260-1.

${ }^{11}$ See Schrama (2005), 274-6. In Germany, Art. 6 I of the Basic Law provides for the special protection of marriage. This probably partially explains the differences between the Dutch and German legal approach to non-marital cohabitation.

${ }^{12}$ Parliamentary Papers II, 2002-2003, no. 28600 VI, no. 104, p. 2.

${ }^{13}$ Art. 1:160 Civil Code: '.. began to live together with another as if they are married'.

${ }^{14}$ Asser-De Boer (2006), no. 646 and no. 648; Cohen Henriquez and Moltmaker (1977), 44; Davids (1983), 84; Minkenhof (1983), 240.

${ }^{15}$ Parliamentary Papers II, 2002-2003, 28600 VI, no. 104.

${ }^{16}$ Art. 7:267 Civil Code: A minimum duration of two years of co-residence in which the applicant should have had a joint durable household with the tenant, no abuse, and financial guarantees in order to ensure that the landlord will be paid.

${ }^{17}$ Art. 24 lid 2, b and c Successiewet 1956.

${ }^{18}$ Parliamentary Papers II, 1979-1980, 16 016, no. 3, p. 1 and 8-9 and no. 7, 20.

${ }^{19}$ Parliamentary Papers II, 1979-1980, 16 016, no. 3, 8-9 and no. 7, p. 17 and 19.

${ }^{20}$ Art. 24 lid 2, sub a Successiewet 1956.

${ }^{21}$ Parliamentary Papers II, 2001-2002, 28 015, no. 6, 9.

${ }^{22}$ In order to qualify under this new definition, a surviving partner should have had a joint durable household continuously for at least 6 months up until the moment of the other partner's death. A joint durable household will only be taken into account if the deceased and the surviving partner have been registered at the same address in the General Population Registers and if the partners concluded a cohabitation contract signed by a notary. In this contract, a duty to take care of each other has to be included. In addition, the partners should have opted to be qualified as tax partners under the Income Tax Act 2001.

${ }^{23}$ Art. 1:431 Civil Code, Art. 1:432 s. 1 Civil Code and art. 4:435 s. 4 Civil Code.

${ }^{24}$ Asser-De Boer (2006), no. 1139.

${ }^{25}$ Parliamentary Papers II, 1979-1980, 15 350, no. 8, 3.

${ }^{26}$ Art. 1:379 and 383 s. 3 Civil Code respectively art. 1:451 s. 1 and 452 s. 3 Civil Code.

${ }^{27}$ Parliamentary Papers II, 1985-1986, 19 259, no. 3, 10.

${ }^{28}$ See for instance Council of State (Raad van State), 15 May 1991 JABW 1991, 174.

${ }^{29}$ These new rules did not only apply to the Social Assistance Act, but were extended to many other acts in social security law.

${ }^{30}$ Parliamentary Papers II, 1985-1986, 19 259, no. 3, pp. 8-10, no. 10 and no. 13 and Handelingen II, 22 April 1986, 4718-20.

${ }^{31}$ Supreme Court 22 February 1985, NJ 1986, 82.

${ }^{32}$ Art. 6:108 CC.

${ }^{33}$ Art. 1.2 s. 2 Income Tax Act 2001.

${ }^{34}$ Although a considerable amount of cases have been brought to the courts concerning the exact interpretation of the definitions in the different legal provisions. For instance: Supreme Court 3 June 2005 LJN AS5961 (to be found at http://www.rechtspraak.nl under reference to the LJN number); Central Appeals Tribunal (for the public service and for social security matters) 8 May 2007 LJN: BA4634; Court of Appeal of The Hague 28 May 2004, LJN AP9574.

${ }^{35}$ The same applies to male registered partners in a heterosexual partnership, since a registered partnership does not bring about legal parentage for the male or female partner of the birth mother of the child. However, registered partners usually exercise joint parental authority by operation of law (art. 1:253aa and sa Civil Code). See also Vonk (2007).

${ }^{36}$ The consent of the mother is required when the child is under the age of 16 years: art. 1:204 s. 1 sub c Civil Code.

${ }^{37}$ Art. 1:199 sub c and art. 1:200 Civil Code respectively art. 1:199 sub a Civil Code.

${ }^{38} \mathrm{Jansen}$ et al (2007): 10 per cent of male registered fathers did not recognize their first child.

${ }^{39}$ If he does not, a man's paternity may be judicially determined by a court, but this procedure has to be initiated by the mother or the child (Art. 1:207 Civil Code). There are no empirical data on the number of judicial determinations of paternity.

${ }^{40}$ Art. 1:253b Civil Code.

${ }^{41}$ Art. 1:252 Civil Code.

${ }^{42}$ Art. 252 s. 2 Civil Code.

${ }^{43}$ Boele-Woelki et al, Dutch report on parental authority, Commission on European Family Law website: http://www2.law.uu.nl/priv/cefl.

${ }^{44}$ Art. 1:251 Civil Code.

${ }^{45}$ The child's consent is required if it is at least 12 years of age. 
${ }^{46}$ See for instance, Supreme Court 18 November 2005, LJN: AT6843; Supreme Court 16 June 2006, LJN: AW1860; Supreme Court 20 October 2006, LJN: AY6202. In a limited number of cases, the man does not obtain the court's permission, see for instance Court of Appeal of The Hague, 10 May 2006, LJNAY6460.

${ }^{47}$ Art. 1:253c Civil Code.

${ }^{48}$ Supreme Court 27 May 2005, NJ 2005, 485; Supreme Court 28 April 2006, LJN: AV0656.

${ }^{49}$ Schrama (2005).

${ }^{50}$ de Graaf (2004).

${ }^{51}$ There is a growing body of case law concerning the interpretation of cohabitation contracts. For example, Supreme Court 22 September 2006, NJ 2006, 521; District Court of Middelburg, 15 May 2002, LJN AE3258; District Court of Utrecht 18 May 2005, LJN AT5819.

${ }^{52}$ See Forder and Verbeke (2006), 553-5; Schrama (2005), 263.

${ }^{53}$ Supreme Court 8 October 1982, NJ 1984, 2; Supreme Court 16 January 1987, NJ 1987, 912; Supreme Court 26 May 1989, NJ 1990, 23; Supreme Court 17 December 2004, LJN: AR3636, http://www.rechtspraak.nl); Supreme Court 22 September 2006, NJ 2006, 521. See also Schrama (2000), 63-5.

${ }^{54}$ Schrama (2004), 270-1. Supreme Court 24 February 2006, LJN AU8178.

${ }^{55}$ Schrama (2004), 445-55. District Court of Rotterdam 14 December 2004, NJ Feitenrechtspraak 2005, 130; District Court of Utrecht 18 May 2005, LJN AT5819; District Court of Middelburg 27 April 2006 LJN AY8267; District Court of Zwolle 9 March 2006, LJN AY5727.

${ }^{56}$ Relationship is relevant: Supreme Court 8 October 1982, NJ 1984, 2; Supreme Court 16 January 1987, NJ1987, 912; Supreme Court 26 May 1989, NJ 1990, 23; Supreme Court 17 December 2004, LJN: AR3636; Court of Appeal Amsterdam 18 December 2003 LJN AR 5527; District Court of Rotterdam 14 December 2004, NJ Feitenrechtspraak 2005, 130. Relationship not taken into account: the case law of the lower courts on property disputes and compensation claims: Schrama (2000), 64-5; Schrama (2004), 448-52. See also Supreme Court 24 February 2006, LJN AU8178.

${ }^{57}$ The courts sometimes refuse to award compensation for contributions with respect to the purchase or rebuilding of a house owned by the other partner. However, the courts solve certain other problems in a more flexible way, eg, with respect to the application of the provisions regarding joint tenancies. See eg: Supreme Court 22 September 2006, NJ 2006, 521; Court of Appeal of Amsterdam 18 December 2003 LJN AR 5527 and the rather extreme decision by the District Court of Rotterdam 14 December 2004, NJ Feitenrechtspraak 2005, 130.

${ }^{58}$ Art. 4:13 Civil Code.

${ }^{59}$ Art. 4:10 S. 1 sub a Civil Code.

${ }^{60}$ Art. 4:82 Civil Code.

${ }^{61}$ Art. 4:83 Civil Code.

${ }^{62}$ Art.4:28 Civil Code.

${ }^{63}$ Art.4:29 and 30 Civil Code.

${ }^{64}$ Art. 316,334 and 338 Criminal Code.

${ }^{65}$ Art. 137 Criminal Code.

${ }^{66}$ Art. 189 s. 2 Criminal Code.

${ }^{67}$ Art. 65 s. 2 Criminal Code.

${ }^{68}$ Art. 217 s. 3 Criminal Procedural Code.

${ }^{69}$ Art. 96 a s. 3 sub a; art. 126 nc s. 3 , art. 126 nf s. 3 Criminal Procedural Code.

${ }^{70}$ Art. 260 s. 2, 302 and 336 s. 2 Criminal Procedural Code.

${ }^{71}$ Supreme Court 31 May 2005, NJ 2005, 531 annotated by J. de Boer. See on this judgement: Schrama, (2006), 257-60.

${ }^{72}$ Supreme Court 1 November 2005, NJ 2006, 106.

${ }^{73}$ Parliamentary Papers II, 2002-2003, 28 484, no. 5, p. 3 en pp. 5-6.

${ }^{74}$ Art. 1 Criminal Code.

${ }^{75}$ Vonk, (2004).

${ }^{76}$ Although some unsuccessful attempts have been made to improve the legal position of these children, for instance Parliamentary Papers II, 2000-2001, 27 047, no. 10.

${ }^{77}$ See also Vonk (2007).

${ }^{78}$ Schrama (2008).

${ }^{79}$ This is, however, not undisputed in the Dutch legal literature. Punselie (2007) argues that the legal system should encourage parents to take responsibility for their children by marrying, since this would provide a financially better arrangement than non-marital cohabitation, in particular with respect to post-divorce situations. If non-married parents would obtain joint parental authority by operation of law, any incentive to consider the legal organization of their family would disappear. 
${ }^{80}$ Forder and Verbeke (2005) 546-55; Quispel (2005); Schrama (2004), 556-69. See also Vlaardingerbroek, (2007), p. 249.

${ }^{81}$ Asser-Perrick 6, (2002), no. 5.

${ }^{82}$ Schmidt (1881), 495.

${ }^{83}$ Schmidt (1881), 525 .

${ }^{84}$ Art. 137 Criminal Code.

${ }^{85}$ Schmidt (1881), 79.

${ }^{86}$ Art. 189 s. 2 Criminal Code.

${ }^{87}$ Art. 65 s. 2 Criminal Code.

${ }^{88}$ Such as Art. 65, Art. 137, Art. 189 s. 2 Criminal Code.

${ }^{89}$ Barlow et al (2005), 85.

${ }^{90}$ Supreme Court 21 March 1986, NJ 1986, 585 (parental responsibilities), Central Appeals Tribunal (for the public service and for social security matters) 13 November 1986, AB 1987, 456 (certain unjustified differences with respect to the compensation of costs for military employees), Supreme Court 23 September 1988, NJ 1989, 740 (provisions on the choice of a child's surname were in breach of the equality principle); Court of Appeal of Arnhem 20 Augustus 2004, LJN AQ9883 (income tax differences).

${ }^{91}$ Law Commission of Canada, News Release 24 June 1999.

\section{REFERENCES}

Antokolskaia, M. (2006) Harmonisation of Family Law in Europe: A Historical Perspective, Antwerp, Belgium: Intersentia.

Asser-De Boer, J. (2006) Personen- en familierecht, Deventer, The Netherlands: Kluwer.

Asser-Perrick, S. (2002) Erfrecht en schenking, Deventer, The Netherlands: Kluwer.

Atkin, B. (2003-2004) 'The challenge of unmarried cohabitation - The New Zealand response', Family Law Quarterly 37, 303-25.

Barlow, A., Duncan, S., James, G. and Park, A. (2005) Cohabitation, Marriage and the Law, Oxford: Hart Publishing.

Barlow, A. and James, G. (2004) 'Regulating marriage and cohabitation in 21st century Britain', Modern Law Review 67 (2), 143-76.

Boele-Woelki, K., Schrama, W. M. and Vonk, M. Report on Parental Authority, available at the CEFL's website: http://www2.law.uu.nl/priv/cefl/(21.01.2008).

Cohen Henriquez, E. and Moltmaker, J. K. (1977) Privaatrechtelijke en fiscale aspecten van samenlevingsvormen buiten huwelijk, Deventer, The Netherlands: Kluwer.

Davids, W. J. M. (1983) 'Alimentatie ... Niet in de lengte, wel in de breedte' in W. Breemhaar and T. R. Hidma (eds), Samenleven Samenwerken, Deventer, The Netherlands: Kluwer, 77-85.

de Graaf, A. (2004) 'Helft samenwoners heeft samenlevingscontract', Webmagazine 22 maart 2004, CBS. http://www.cbs.nl/nl/publicaties/artikelen/algemeen/webmagazine (21.01.2008).

Forder, C. and Verbeke, A. (2005) Gehuwd of niet, Maakt het wat uit?, Antwerp, Belgium, Intersentia.

Freiburghaus-Arquint, D. (2000) 'Cohabitation non maritale: Etat de la question en droit suisse' in F. Guillaume and R. Arn (eds), Cohabitation non maritale, Evolution récente en droit suisse et étranger, Actes du Colloque de Lausanne du 23 février 2000, Genève, Switzerland: Librairie Droz, 109-25.

Hausmann, R. and Hohloch, G. (2004) Das recht der nichtehelichen Lebensgemeinschaft, Berlin, Germany: Erich Schmid Verlag.

Hertz, F. (2004) 'Property and support claims upon termination of non-marital relationships in the non-United States', International Family Law, 8-17.

Holland, W. (2000) 'Intimate relationships in the new millennium: The assimilation of marriage and cohabitation?', Revue Canadienne de Droit Familial 17, 114-68.

Jansen, M. Boeli-Woelki, K., Curry-Sumner, I. and Schrama, W. (2007) Huwelijk of geregistreerd partnerschap?, Deventer, The Netherlands: Kluwer.

Kiernan, K. (2001) 'The rise of cohabitation and childbearing outside marriage in western Europe', IJLPF 15, 1-21.

Kiernan, K. (2002) 'The state of European Unions: An analysis of partnership formation and dissolution' in M. Macura and G. Beets (eds.), Dynamics of Fertility and Partnership in Europe, Insights and Lessons from Comparative Research, Volume 1, New York: United Nations, 57-76. 
Liefbroer, A. C. and Dykstra, P. A. (2000) Levenslopen in verandering, Een studie naar ontwikkelingen in de levenslopen van Nederlanders geboren tussen 1900 en 1970, Den Haag, The Netherlands: Sdu Uitgevers.

Michel, J-P. (2000) R. Arn (eds.), 'Cohabitation non maritale en droit comparé: L'exemple français' in F. Guillaume (eds.), Cohabitation non maritale, Evolution récente en droit suisse et étranger, Genève, Switzerland: Librairie Droz, 23-31.Actes du Colloque de Lausanne du 23 février 2000.

Minkenhof, A. A. L. (1983) 'Over de "levensgezel" in het beschermingsbewind' in W. Breemhaar and T. R. Hidma (eds.), Samenleven Samenwerken, Deventer, The Netherlands: Kluwer, 233-41.

Noack, T. (2001) 'Cohabitation in Norway: An accepted and gradually more regulated way of living', IJLPF 15, 102-17.

Punselie, L. (2007) 'Kinderen van (ex-) samenwonenden', FJR 29, 272-6.

Quispel, Y. (2005) 'Niet-geregistreerde samenwoners vanuit het perspectief van het huwelijksvermogens- en erfrecht', FJR 27, 40-6.

Schmidt, H. J. (1881) Geschiedenis van het Wetboek van Strafrecht, Eerste en tweede deel, Haarlem, The Netherlands: Tjeenk Willink.

Schrama, W. M. (2000) Vermogensrecht voor ongehuwde samenlevers, Deventer, The Netherlands: Kluwer.

Schrama, W. M. (2004) De niet-huwelijkse samenleving in het Nederlandse en Duitse recht, Deventer, The Netherlands: Kluwer.

Schrama, W. M. (2005) 'General lessons for Europe based on a comparison of the legal status of non-marital cohabitants in The Netherlands and Germany' in K. Boele-Woelki (ed), Common Core and Better Law in European Family Law, Antwerp, Belgium: Intersentia, 257-81. European Family Law Series No. 10.

Schrama, W. M. (2006) 'Waarom moet een verdachte naar het stadhuis gaan? Een pleidooi voor aanpassing van het straf(proces) recht aan het ongehuwd samenleven', NJB 81, 257-60.

Schrama, W. M. and Boele-Woelki, K. (2005) Die nichteheliche Lebensgemeinschaft im niederländischen Recht' in J. Scherpe and N. Yassari (eds), Die Rechtsstellung nichtehelicher Lebensgemeinschaften - The Legal Status of Cohabitants, Tübingen, Germany: Mohr Siebeck, 307-74.

Schrama, W. M. (2008) 'Family function over family form in the law on parentage?', Utrecht Law Review, 4, 83-98.

Vlaardingerbroek, P. (2007) 'Naar een dwingend relatierecht?', FJR 29, 249.

Vonk, M. (2004) 'One, two or three parents? Lesbian co-mothers and a known donor with "family life" under Dutch law’, IJLPF 18, 103-17.

Vonk, M. (2007) Children and Their Parents, A Comparative Study of the Legal Position of Children with Regard to Their Intentional and Biological Parents in English and Dutch Law, Antwerp, Belgium: Intersentia.

Vonk, M. (2007) 'Parent-child relationships in Dutch family law' in I. Schwenzer (ed.), Tensions between Legal, Biological and Social Conceptions of Parentage, Antwerp, Belgium: Intersentia, 279-307. 